\title{
Functional replacement of the Escherichia coli hfq gene by the homologue of Pseudomonas aeruginosa
}

\author{
Elisabeth Sonnleitner, Isabella Moll and Udo Bläsi
}

Institute of Microbiology and Genetics, Vienna Biocentre, Dr Bohrgasse 9, 1030 Vienna, Austria
Author for correspondence: Udo Bläsi. Tel: +4314277 54609. Fax: +43142779546. e-mail: udo.blaesi@univie.ac.at

The 102 aa $\mathrm{Hfq}$ protein of Escherichia coli $\left(\mathrm{Hfq}_{\mathrm{EC}}\right)$ was first described as a host factor required for phage $Q \beta$ replication. More recently, $\mathrm{Hfq}$ was shown to affect the stability of several $E$. coli mRNAs, including ompA mRNA, where it interferes with ribosome binding, which in turn results in rapid degradation of the transcript. In contrast, $\mathrm{Hfq}$ is also required for efficient translation of the $E$. coli and Salmonella typhimurium rpos gene, encoding the stationary $\sigma$ factor. In this study, the authors have isolated and characterized the $\mathrm{Hfq}$ homologue of Pseudomonas aeruginosa $\left(\mathrm{Hfq}_{\mathrm{P}_{\mathrm{a}}}\right.$ ), which consists of only 82 aa. The $68 \mathrm{~N}$ terminal amino acids of $\mathrm{Hfq}_{P a}$ show $\mathbf{9 2} \%$ identity with $\mathrm{Hfq}_{E \mathrm{C}^{*}} \mathrm{Hfq}_{P}$ was shown to functionally replace $\mathrm{Hfq}_{\mathrm{Ec}}$ in terms of its requirement for phage $Q \beta$ replication and for rpoS expression. In addition, $\mathrm{Hfq}_{P_{a}}$ exerted the same negative effect on $E$. coli ompA mRNA expression. As judged by proteome analysis, the expression of either the plasmid-borne $h f_{P a}$ or the $h f q_{E c}$ gene in an $E$. coli $\mathrm{Hfq}^{-} \mathrm{RpoS}^{-}$strain revealed no gross difference in the protein profile. Both $\mathrm{Hfq}_{E c}$ and $\mathrm{Hfq}_{\mathrm{Pa}}$ affected the synthesis of approximately 26 RpoSindependent $E$. coli gene products. These studies showed that the functional domain of $\mathbf{H f q}$ resides within its $\mathbf{N}$-terminal domain. The observation that a $\mathbf{C}$ terminally truncated $\mathrm{Hfq}_{E c}$ lacking the last 27 aa $\left[\mathrm{Hfq}_{E c(75)}\right]$ can also functionally replace the full-length $E$. coli protein lends further support to this notion.

Keywords: global regulator, $\mathrm{Hfq}$, omp $A, r p o S$

\section{INTRODUCTION}

Escherichia coli host factor I (HF1/Hfq), the product of the $h f q$ gene, was first described as a factor required for phage $\mathrm{Q} \beta$ replication (de Fernandez et al., 1968). More recent experiments have suggested that $\mathrm{Hfq}$ stimulates $\mathrm{Q} \beta$ replication by melting out the $3^{\prime}$ end of $\mathrm{Q} \beta$ plusstrand RNA, which appears to facilitate access of the replicase (Schuppli et al., 1997).

Hfq has been reported to positively regulate the rpoS gene encoding the $\sigma^{\mathrm{s}}$ subunit of RNA polymerase (Brown \& Elliot, 1996; Muffler et al., 1996). It has been suggested that $\mathrm{Hfq}$ activates $r p o S$ translation by altering the secondary structure, sequestering its RBS (Brown \& Elliot, 1997; Cunning et al., 1998; Muffler et al., 1996).

Abbreviations: $\mathrm{Hfq}_{E C^{\prime}} \mathrm{Hfq}$ protein of Escherichia coli; $\mathrm{Hfq}_{E C(75)}$ C-terminally truncated $\mathrm{Hfq}_{E \mathrm{C}^{\prime}}$ lacking the last $27 \mathrm{aa} ; \mathrm{Hfq}_{P^{\prime}}$, $\mathrm{Hfq}$ homologue of Pseudomonas aeruginosa; UTR, untranslated region.
However, several other factors, including HNS and two small RNAs (DsrA and OxyS), are also involved in rpoS mRNA translation (Sledjeski et al., 1996, 2001; Wassarman et al., 2001; Zhang et al., 1998). Whereas DsrA RNA seems to stimulate the translation of $r p o S$ by pairing with the mRNA and melting the secondary structure (Majdalani et al., 1998), OxyS RNA represses rpoS translation by binding to Hfq (Zhang et al., 1998). Although OxyS RNA does not prevent the binding of $\mathrm{Hfq}$ to the rpoS mRNA it apparently abrogates the stimulatory effect of $\mathrm{Hfq}$ on rpoS translation.

Hfq has been implicated in affecting the stability of the mRNAs of mutS, miaA, hfq (Tsui et al., 1997) and ompA (Vytvytska et al., 1998). Vytvytska et al. (2000) have shown that $\mathrm{Hfq}$ binds to the $5^{\prime}$-untranslated region (UTR) of ompA in the vicinity of the RBS, preventing translation and thereby indirectly subjecting the mRNA to degradation.

The E. coli $\mathrm{Hfq}$ protein $\left(\mathrm{Hfq}_{E c}\right)$ is heat-stable and consists of 102 aa. Immunofluorescence microscopy 
indicated that the majority of $\mathrm{Hfq}_{E c}$ is present in the cytosol and that it is most likely associated with the translation machinery; only a minor fraction appears to be associated with the nucleoid (Azam et al., 2000). Mutations in the E. coli $b f q$ gene $\left(b f q_{E c}\right)$ caused pleiotropic effects. The insertion of an $\Omega$ cassette at the beginning of $h f q$ resulted in a decreased growth rate, an increase in cell size, osmo-sensitivity and an increased sensitivity to UV light, and it also affected the supercoiling of plasmids (Tsui et al., 1994). Furthermore, a bfq null-mutant did not synthesize glycogen, was starvation and multiple-stress sensitive and, as expected from its positive effect on rpoS translation, showed a down-regulation of RpoS-regulated genes (Muffler et al., 1997). Taken together with the above-described effects on specific genes, these results suggested that Hfq acts as a global regulator involved in the regulation of RpoS-dependent and RpoS-independent genes. Moreover, Hfq homologues have been reported to stimulate synthesis of the heat-stable enterotoxin in Yersinia enterocolitica (Nakao et al., 1995) and of the NifA protein in Azorhizobium caulinodans (Kaminski et al., 1994). Also, the Hfq homologue of Brucella abortus appears to be a major determinant of virulence in mice (Robertson \& Roop, 1999).

As an opportunistic human pathogen Pseudomonas aeruginosa causes serious infections in immunocompromised hosts, but rarely infects healthy individuals (Bodey et al., 1983). It has been previously shown that RpoS of $P$. aeruginosa is required for the expression of severe-stress-resistance genes as well as for the expression of several virulence genes (Suh et al., 1999). Since Hfq is required in both E. coli and Salmonella typhimurium for the efficient translation of rpoS, we were interested to determine whether a Hfq homologue is present in $P$. aeruginosa. Here, we report the isolation of the $P$. aeruginosa $h f q$ gene $\left(h f q_{P a}\right)$. We also show that the $\mathrm{Hfq}$ protein of $P$. aeruginosa $\left(\mathrm{Hfq}_{P a}\right)$ can functionally replace $\mathrm{Hfq}_{E c}$.

\section{METHODS}

Bacterial strains, plasmids and growth conditions. The strains and plasmids used in this study are listed in Table 1. E. coli IM1101 was constructed by transducing $r p o S-354:$ : Tn 10 from E. coli RH90 to E. coli AM111, using phage P1 and standard procedures (Miller, 1972). Unless indicated otherwise, bacterial cultures were grown at $37^{\circ} \mathrm{C}$ in Luria-Bertani (LB) medium (Miller, 1972), supplemented with the appropriate antibiotics. Antibiotics were added to the following final concentrations : $100 \mu \mathrm{g}$ ampicillin $\mathrm{ml}^{-1}, 25 \mu \mathrm{g}$ kanamycin $\mathrm{ml}^{-1}$, $10 \mu \mathrm{g}$ chloramphenicol ml $\mathrm{m}^{-1}, 15 \mu \mathrm{g}$ gentamicin $\mathrm{ml}^{-1}$ and $20 \mu \mathrm{g}$ tetracycline $\mathrm{ml}^{-1}$.

Construction of plasmids used in this study. pESE102, pESE75 and pESP82 (Table 1) were constructed as follows. The $h f q_{E c}$ gene [nucleotide -16 to +310 with regard to the $\mathrm{A}$ (position +1 ) of the start codon] was amplified by PCR using pHFQ607 and the forward primer E15 (5'-TTTTTTGAATTCGGATCCGTGAGGAAAAGAGAGAATGGCTAAGGGG-3'), containing a $B a m \mathrm{HI}$ site (bold), together with the reverse primer
5'-CCCGAATTCTTATTCGGTTTCGCTGTCC-3', containing an EcoRI site (bold). The DNA fragment was cleaved with BamHI and EcoRI, and then cloned into the corresponding sites of pUC19, resulting in pESE102.

Plasmid pESE75 was constructed by first amplifying a fragment carrying the $3^{\prime}$-terminally truncated $h f q_{E c}$ gene [nucleotide -16 to $+225 ; h f q_{E c(75)}$ ] by means of PCR using pHFQ607 and the forward primer E15 together with the reverse primer 5'-TTTTTTTGGATCCCTGCAGttactaGGCGTTGTTACTGTGATGAG-3' containing a PstI site (bold) and two stop codons (lower case). This PCR fragment was then inserted into the BamHI-PstI sites of vector pUC18.

The putative $h f q_{P a}$ gene (position 5548396-5548644 of the $P$. aeruginosa genomic sequence, www.pseudomonas.com; accession no. AE004091) was amplified by PCR from P. aeruginosa PAO1 genomic DNA using the forward primer X14 (5'-TTTTTTTTTTGGATCCCTATTCGACTAC-3'), containing a $B a m \mathrm{HI}$ site (bold), and the reverse primer $\mathrm{Y} 14$ (5'-TTTTTTTTTTCTGCAGCCTGTTCCCACCACC-3'), containing a PstI site (bold). The $h f q_{P a}$ gene fragment (nucleotides -46 to +296) was digested with Bam HI and Pst I, and then cloned into the corresponding sites of pUC18, resulting in pESP82.

Plasmids pDLE102, pDLE75 and pDLP82 are derivatives of pACYC184 and were constructed as follows. pESE102, pESE75 and pESP82, respectively, were cleaved with PvuII. The resulting fragments, containing the lac promoter and the $h f q_{E c}, h f q_{E c(75)}$ or $h f q_{P a}$ gene, were inserted into the EcoRV site of pACYC184, resulting in pDLE102, pDLE75 and pDLP82, respectively.

Plasmid pESPGm is a derivative of pESP82. The gentamicin cassette, aacC1, from pUCP24 was amplified by PCR using the primer pair B15 (5'-TTTTTTTTTTGATATCGGTACCTCTAGACCAGCGGCACCAGCGGC-3') and C15 (5'-TTTTTTTTTGATATCGGTACCGCGGCGTTGTGAC-3'); both of these primers contained a KpnI site (bold). The PCR fragment was digested with $K p n I$ and cloned into the corresponding site of plasmid pUC19. The resulting pUC19 derivative was then cleaved with PvuII and HincII, and the fragment was inserted into the HincII site of pESP82 to generate pESPGm, which bore the insertionally inactivated $h f q_{P a}$ gene.

The ompA-lacZ fusion plasmid, pIMZ, was constructed as follows. A constitutive lac promoter without operator sites was amplified by PCR from pUHE21-2 using the forward primer C10 (5'-AAATCTAGAATTCCCTTTCGTCTTCACCTCGAG-3'), containing a XbaI site (bold), and the reverse primer C12 (5'-AAAAAAGAATTCATCTAAGTATCATTGTTATCCG-3'), containing an EcoRI site (bold). The resulting fragment was cleaved with both EcoRI and XbaI and ligated to a $\sim 1300 \mathrm{bp}$ EcoRI-HindIII fragment isolated from pKSO325, containing the full-length ompA gene. This fragment was used to amplify the constitutive lac promoter together with the $5^{\prime}$-UTR of ompA up to nucleotide +69 by PCR with the forward primer $\mathrm{C} 10$ and the reverse primer E12 (5'-AAAAAAGGATCCGGAGCGGCCTGCGCTAGGG$\left.3^{\prime}\right)$, containing a Bam HI site (bold). This fragment was then cloned into the $\mathrm{XbaI}$ and $\mathrm{BamHI}$ sites of pRB381 in-frame with lacZ, resulting in pRBompA-lacZ. This plasmid was then digested with EcoRI and BamHI. The EcoRI-BamHI fragment was cloned into plasmid pUHE21-2 downstream of the lac promoter. The resulting pUHE21-2 derivative was then cleaved with $\mathrm{XhoI}$ and $\mathrm{BamHI}$, and the fragment containing the lac promoter and the $5^{\prime}$ end of ompA was inserted into the 
Table 1. Bacterial strains and plasmids

\begin{tabular}{|c|c|c|}
\hline Strains/plasmids & Genotype/relevant features & Source/reference \\
\hline \multicolumn{3}{|l|}{ P. aeruginosa } \\
\hline PAO1 & & Holloway (1955) \\
\hline \multicolumn{3}{|l|}{ E. coli } \\
\hline AM111 & 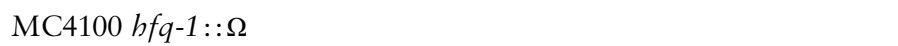 & Muffler et al. (1996) \\
\hline AM111F' & AM111F' proAB lacl $I^{\mathrm{a}} \operatorname{lac} Z \Delta \mathrm{M} 15 \mathrm{Tn} 10 ; \mathrm{Tc}^{\mathrm{R}}$ & Lab. stock \\
\hline IM1101 & MC4100 hfq-1:: $\Omega$ rpoS-354::Tn10 & This study \\
\hline RH90 & MC4100 rpoS-354:: $\operatorname{Tn} 10$ & Lange \& Hengge-Aronis (1991) \\
\hline \multicolumn{3}{|l|}{ Plasmids } \\
\hline pUC18 & colE1 ori; $\mathrm{Amp}^{\mathrm{R}}$ & Yanisch-Perron et al. (1985) \\
\hline pUC19 & colE1 ori $; \mathrm{Amp}^{\mathrm{R}}$ & Yanisch-Perron et al. (1985) \\
\hline pESE102 & pUC19 with $h f q_{E c}$ cloned under $\mathrm{P}_{l a c}$ control & This study \\
\hline pESE75 & pUC18 with $h f q_{E c(75)}$ cloned under $\mathrm{P}_{l a c}$ control & This study \\
\hline pESP82 & pUC18 with $h f q_{P a}$ cloned under $\mathrm{P}_{l a c}$ control & This study \\
\hline pESPGm & pESP82 with $h f q_{P a}:: a a c C-1$ & This study \\
\hline pUCP24 & pUC18 derivative carrying an aacC-1 cassette; $\mathrm{Gm}^{\mathrm{R}}$ & West et al. (1994) \\
\hline pKSO325 & Harbours E. coli ompA & Ried et al. (1994) \\
\hline pOU251 & Single-copy-number vector at $28^{\circ} \mathrm{C}$ with oriR; $\mathrm{Amp}^{\mathrm{R}}$ & J. Jakobsen, University of Vienna \\
\hline pRB381 & E. coli-B. subtilis shuttle vector; $A \mathrm{mp}^{\mathrm{R}}$ & Brückner (1992) \\
\hline pRB-ompA-lacZ & $\begin{array}{l}\text { pRB381 with an ompA-lacZ fusion gene under the control of a } \\
\text { constitutive } \mathrm{P}_{l a c}\end{array}$ & This study \\
\hline pIMZ & pOU251 with an ompA-lacZ fusion gene under control of $\mathrm{P}_{l a c}$ & This study \\
\hline pACYC184 & P15A ori $;$ Tet $^{\mathrm{R}}, \mathrm{Kan}^{\mathrm{R}}$ & Rose (1988) \\
\hline pDLE102 & pACYC184 with $h f q_{E c}$ cloned under $\mathrm{P}_{l a c}$ control & This study \\
\hline pDLE75 & pACYC184 $h f q_{E c(75)}$ cloned under $\mathrm{P}_{l a c}$ control & This study \\
\hline pDLP82 & pACYC184 $h f q_{P a}$ cloned under $\mathrm{P}_{l a c}$ control & This study \\
\hline pHFQ607 & $\begin{array}{l}\text { E. coli hf } q \text { gene cloned under transcriptional control of a phage T7 } \\
\text { promoter }\end{array}$ & Kajitani et al. (1994) \\
\hline pUHE21-2 & colE1 ori $; \mathrm{Amp}^{\mathrm{R}}$ & Lanzer \& Bujard (1988) \\
\hline
\end{tabular}

corresponding sites of the single-copy, $\left(28^{\circ} \mathrm{C}\right) /$ transcriptional-fusion vector pOU251 in-frame with lacZ, resulting in pIMZ.

Q $\beta$ plating assay. Overnight cultures $(100 \mu \mathrm{l})$ of E. coli AM111F' harbouring pUC18, pESE102, pESE75 or pESP82 were diluted in $5 \mathrm{ml} \mathrm{LB}$ and the corresponding $h f q$ genes were induced by adding IPTG to a final concentration of $3 \mathrm{mM}$. The cultures were grown at $37^{\circ} \mathrm{C}$ until they reached an $\mathrm{OD}_{600}$ of $0 \cdot 4$. Then $200 \mu \mathrm{l}$ aliquots of the cultures and $10 \mu \mathrm{l}$ of the $\mathrm{Q} \beta$ phage dilutions were added to $3 \mathrm{ml}$ top agar. The agar was poured onto LB agar plates supplemented with the appropriate antibiotics and $3 \mathrm{mM}$ IPTG. The p.f.u. $\mathrm{ml}^{-1}$ values were calculated from triplicate assays.

$\boldsymbol{\beta}$-Galactosidase assay. E. coli AM111F' containing $\mathrm{pIMZ}$ and one of the pACYC- $h f q$ derivatives (pDLE102, pDLE75, pDLP82 or pACYC184) was incubated at $28^{\circ} \mathrm{C}$. At an $\mathrm{OD}_{600}$ of $0 \cdot 3$, the pIMZ-encoded ompA-lacZ gene and the respective $h f q$ genes were induced by the addition of IPTG $(3 \mathrm{mM})$. The $\beta$-galactosidase activity (Miller, 1972) was determined from triplicate samples at $28^{\circ} \mathrm{C}$, to maintain a single copy of pIMZ.

Western blot analysis. Cultures of $\mathrm{AM} 11 \mathrm{~F}^{\prime}$, harbouring pESP82, pESPGm, pESE102, pESE75 or pUC18, and strain $\mathrm{RH} 90$ were grown at $37^{\circ} \mathrm{C}$ until they reached an $\mathrm{OD}_{600}$ of $0 \cdot 4$, at which time IPTG was added to a final concentration of $3 \mathrm{mM}$. At an $\mathrm{OD}_{600}$ of $0 \cdot 8$ equal amounts of cells were withdrawn and boiled in Laemmli buffer. The proteins were separated on $12 \%$ SDS-polyacrylamide gels (Laemmli, 1970) and then transferred to a nitrocellulose membrane. The blots were blocked with $5 \%$ dry milk in TBS $\left(8 \mathrm{~g} \mathrm{NaCl}^{-1}, 0 \cdot 2 \mathrm{~g} \mathrm{KCl}\right.$ $\mathrm{l}^{-1}$ and $3 \mathrm{~g}$ Tris-base $\mathrm{l}^{-1}$ in water, $\mathrm{pH} 7 \cdot 5$ ) and then probed with anti-RpoS antibodies (kindly provided by Dr F. Norel, Pasteur Institute, Paris). The antibody-antigen complex was visualized with goat-anti-rabbit immunoglobulin alkaline-phosphatase-conjugated antibodies (Sigma) using the chromogenic substrate nitro blue tetrazolium $\left[2,2^{\prime}\right.$-di- $p$-nitrophenyl-5, $5^{\prime}$ diphenyl-3,3'-(3,3'-dimethoxy-4,4'-diphenylene)-ditetrazolium chloride; BIOMOL] and BCIP (5-bromo-4-chloro-3indolyl phosphate) $p$-toluidine salt (BIOMOL) in alkaline phosphatase buffer $(10 \mathrm{mM} \mathrm{NaCl}, 5 \mathrm{mM} \mathrm{MgCl}, 100 \mathrm{mM}$ Tris/ $\mathrm{HCl}, \mathrm{pH}$ 9.5). The quantification of the protein bands on the Western blots was performed with ImageQuant software (Molecular Dynamics, version 3.3).

Proteome anaylsis. E. coli IM1101 harbouring pUC18, pESE102 or pESP82 was grown in M9 minimal medium containing $0.2 \%(\mathrm{v} / \mathrm{v})$ glycerol to an $\mathrm{OD}_{600}$ of 0.8 and then labelled with $143 \mathrm{pM} \mathrm{L-}\left[{ }^{35} \mathrm{~S}\right]$ methionine (Amersham Pharmacia Biotech; $>37 \mathrm{TBq} \mathrm{mM}^{-1}$ ) for $10 \mathrm{~min}$. Total cellular protein extracts were analysed by two-dimensional gel electrophoresis. Equal amounts of cell material were dissolved in lysis buffer (8 M urea, 4\%, w/v, CHAPS and $40 \mathrm{mM}$ Tris-base) and the cells were disrupted by repeated freezing in liquid $\mathrm{N}_{2}$ and thawing at $37^{\circ} \mathrm{C}$. For the first dimension the Immobiline Dry strip pH 3-10 (18 cm) (Amersham Pharmacia Biotech) 
was used with the following IEF programme: $12 \mathrm{~h}$ rehydration, $1 \mathrm{~h} 500 \mathrm{~V}, 1 \mathrm{~h} 1000 \mathrm{~V}, 4 \mathrm{~h} 8000 \mathrm{~V}$ (IPGphor isoelectric focusing system). Resolution in the second dimension was performed on $12.5 \%$ SDS polyacrylamide gels for $15 \mathrm{~min}$ at $10 \mathrm{~mA}$ and then for $5 \mathrm{~h}$ at $20 \mathrm{~mA}$. Buffers and conditions were used according to the manufacturer's instructions. The gels were dried and then exposed to a Molecular Dynamics Phosphor Imager screen and analysed with PDQuest software (Bio-Rad).

Computer analysis. The protein sequence of $\mathrm{Hfq}_{P a}$ was revealed by comparing the protein sequence of $\mathrm{Hfq}_{E c}$ with the proteins predicted to be encoded by the $P$. aeruginosa genome (Stover et al., 2000), using the sequence-alignment algorithm BLASTP (Altschul et al., 1990). Preliminary sequence data were obtained from the Institute of Genomic Research (TIGR; http://www.tigr.org). Multiple alignments were done with CLUSTAL W (Thompson et al., 1994) and visualized using BOXSHADE. The following (putative) Hfq sequences were compared: Pseudomonas aeruginosa (accession no. AE004091), Pseudomonas putida (NC002947), Pseudomonas syringae (NC002949), Escherichia coli (U00005), Salmonella typhimurium (U48735), Yersinia entercolitica (D28762), Pectobacterium carotovorum (AF039142), Haemophilus influenzae (U32724), Shigella flexneri (AB000785), Aquifex aeolicus (AE000674), Brucella abortus (AF154075), Acidithiobacillus ferrooxidans (NC002923), Azorhizobium caulinodans (X76450), Bacillus halodurans (BA000004), Bacillus subtilis (AL009126) and Clostridium acetobutylicum (AE001437). The name of the funding agency for each of the different bacterial genome projects can be found on the TIGR website.

\section{RESULTS AND DISCUSSION}

\section{Sequence similarity between $\mathrm{Hfq}_{P_{a}}$ and (putative) $\mathrm{Hfq}$ homologues from other bacteria}

After identification of the putative $\mathrm{Hfq}_{P a}$ protein (see Methods), we performed a search for homologous proteins using the sequence alignment algorithm BLASTP. As shown in Fig. $1, \mathrm{Hfq}_{P a}$ shows considerable amino acid similarity to previously identified Hfq homologues from other Gram-negative bacteria ( 73 to $96 \%$ ) (Brown \& Elliott, 1996; Chuang et al., 1999; Deckert et al., 1998; Durand et al., 1997; Fleischmann et al., 1995; Kajitani \& Ishihama, 1991; Kaminski et al., 1994; Nakao et al., 1995; Robertson \& Roop, 1999), whereas lower amino acid similarity (41 to $45 \%$ ) was found with putative Hfa homologues from three Grampositive bacteria. The multiple alignment (Fig. 1) revealed a high conservation of the N-terminal amino acids. There is considerable variation in the C-terminal amino acids, suggesting that the functional domain of Hfq resides within the first 70 aa. This suggestion is supported by the fact that insertion of an $\Omega$ cassette approximately in the middle of $h f q_{E c}$ (nucleotide +117 , after codon 39) rendered the protein inactive, whereas insertion of the cassette at the $3^{\prime}$ end of the gene (nucleotide +236 , after codon 78 ) did not affect the activity of the protein (Tsui et al., 1994). In addition, further support for this assertion stems from the fact that the 82 aa $\mathrm{Hfq}_{P a}$ is only conserved within its first 68 aa. Finally, in the $\mathrm{Hfq}$ homologues of the different Gram-negative bacteria, and to a somewhat reduced extent in that of Gram-positive bacteria, positively charged amino acids are found at invariant positions within the first 70 aa (Fig. 1), suggesting their functional importance in nucleic acid binding.

\section{Both $\mathrm{Hfq}_{P a}$ and $\mathrm{Hfq}_{E C(7)}$ can functionally replace $\mathrm{Hfq}_{E c}$ in phage $\mathrm{Q} \beta$ replication}

Because of the identity between their $\mathrm{N}$-terminal amino acids, we asked whether $h f q_{P a}$ could functionally replace $h f q_{E c}$. Therefore, pESE102 and pESP82 harbouring $b f q_{E c}$ and $h f q_{P a}$, respectively, were constructed. The Hfq proteins of E. coli, S. typhimurium, Y. entercolitica and Pectobacterium carotovorum are nearly identical up to amino acid 75 (Fig. 1). pESE75, encoding the first 75 aa $\left(h f q_{E c(75)}\right)$, was therefore created with the aim of determining whether the $\mathrm{C}$ terminus of $\mathrm{Hfq}_{E c}$ was functionally irrelevant. The expression of $h f q_{E c}, b f q_{P a}$ and $h f q_{E c(75)}$ was verified by Western blot analysis with antibodies against $\mathrm{Hfq}_{E c}$. As judged by quantitative Western blotting, the apparent level of production of $\mathrm{Hfq}_{P a}$ was reduced by approximately threefold when compared to that of both $\mathrm{Hfq}_{E c}$ and $\mathrm{Hfq}_{E c(75)}$ (data not shown), which could result either from a reduced crossreactivity with the antibodies raised against $\mathrm{Hfq}_{E c}$ or from a reduced rate of expression of $h f q_{P a}$ in E. coli.

Since $\mathrm{Hfq}$ is essential for phage $\mathrm{Q} \beta$ replication (Carmichael et al., 1975; de Fernandez et al., 1972), we tested the functionality of $\mathrm{Hfq}_{P a}$ and $\mathrm{Hfq}_{E c(75)}$ in its replication. When compared to strain AM111F' (pESE102) $\left(1.1 \times 10^{10}\right.$ p.f.u. $\left.\mathrm{ml}^{-1}\right)$, no significant difference in the p.f.u. $\mathrm{ml}^{-1}$ value was detected with strain $\mathrm{AM} 111 \mathrm{~F}^{\prime}$ (pESE75) $\left(1 \cdot 0 \times 10^{10}\right.$ p.f.u. $\left.\mathrm{ml}^{-1}\right)$ or strain

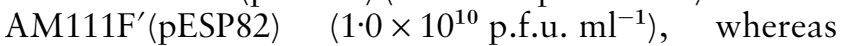
phage $\mathrm{Q} \beta$ was unable to replicate in the control strains

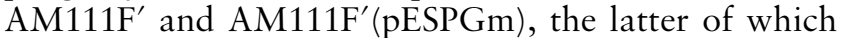
carries the inactivated $h f q_{P a}$ gene (Table 1). Thus, the seemingly reduced $\mathrm{Hfq}_{P a}$ levels present in strain $\mathrm{AM} 111 \mathrm{~F}^{\prime}$ (pESP82) were apparently not limiting for phage $\mathrm{Q} \beta$ replication.

\section{Both $\mathrm{Hfq}_{P a}$ and $\mathrm{Hfq}_{E C(75)}$ affect the expression of $E$. coli ompA in a negative manner}

It has been shown previously that $\mathrm{Hfq}_{E c}$ binds to the $5^{\prime}$ UTR of E. coli ompA mRNA, which results in a decreased rate of expression for ompA (Vytvytska et al., 2000). To test whether the $\mathrm{Hfq}_{P a}$ and the $\mathrm{Hfq}_{E c(75)}$ protein exerted the same effect on the expression of ompA, expression of the pIMZ-encoded ompA-lacZ fusion was monitored in AM111 $\mathrm{F}^{\prime}$ co-transformed with pDLE102 $\left(b f q_{E c}\right)$, pDLE75 $\left(b f q_{E c(75)}\right)$, pDLP82 $\left(b f q_{P a}\right)$ or pACYC184. Both ompA-lacZ and $h f q$ expression was induced at an $\mathrm{OD}_{600}$ of $0 \cdot 3$. At an $\mathrm{OD}_{600}$ of $0 \cdot 6$ the cells were harvested and the $\beta$-galactosidase activities were determined. When compared to $\mathrm{Hfq}_{E c}$, the presence of $\mathrm{Hfq}_{P a}$ or $\mathrm{Hfq}_{E c(75)}$ resulted in a similar decrease in the expression rate of the ompA-lac Z fusion (data not shown), demonstrating that ompA mRNA is also a target for negative regulation by $\mathrm{Hfq}_{P a}$ and by $\mathrm{Hfq}_{E c(75)}$. 

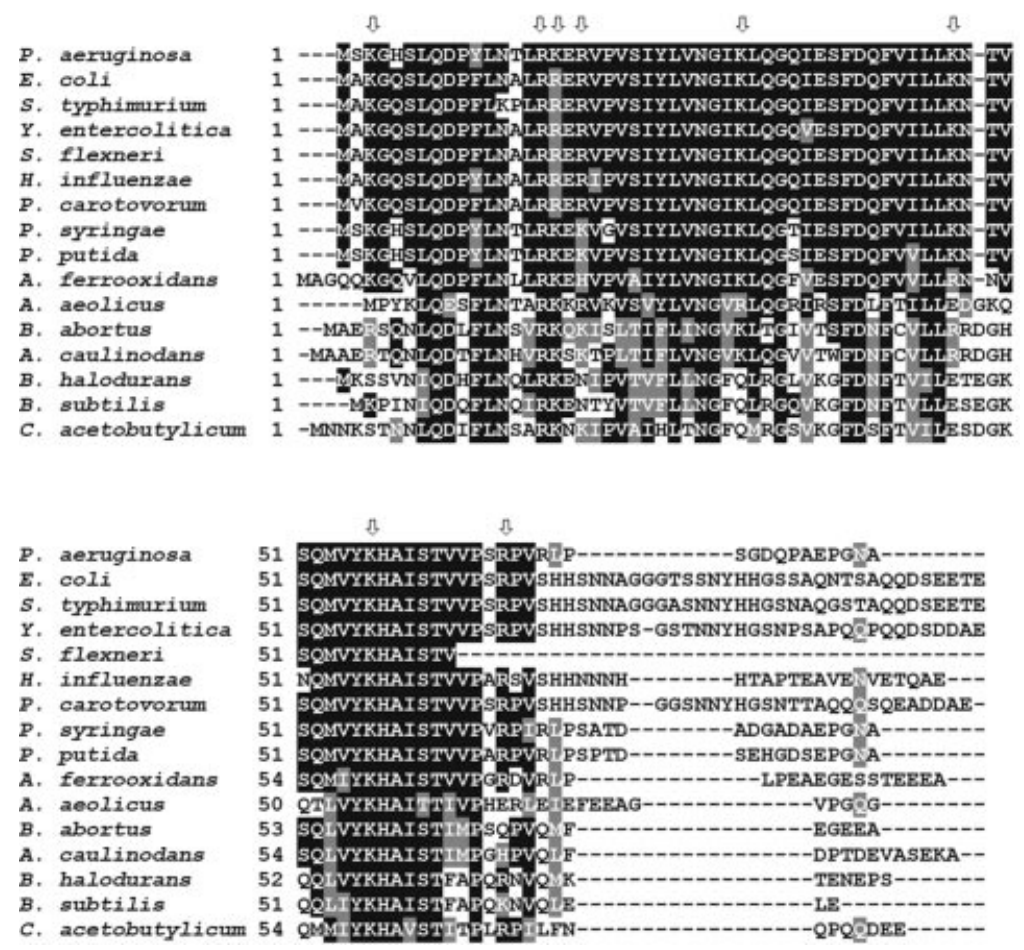

Fig. 1. Sequence of $\mathrm{Hfq}_{\mathrm{Pa}}$ and (putative) $\mathrm{Hfq}$ homologues from Gram-positive and -negative bacteria. Approximately the first 70 aa of the N-terminal of $\mathrm{Hfq}$ are highly homologous. Identical amino acids are highlighted black, whereas conservative exchanges are highlighted grey. Positively charged residues, at invariant positions, are indicated by an arrow. (a)

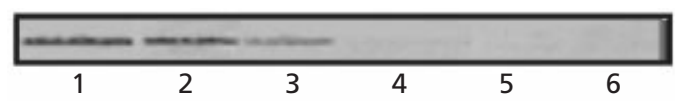

(b)

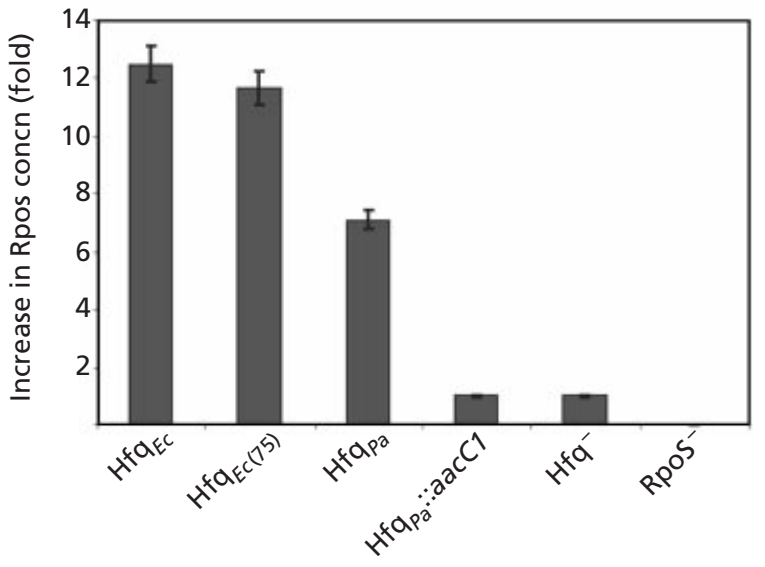

Fig. 2. Both $\mathrm{Hfq}_{P a}$ and $\mathrm{Hfq}_{E c(75)}$ stimulate the expression of $r p o S$ in E. coli. (a) Western blot analysis was carried out as described in Methods. Only the relevant section of the immunoblot showing the RpoS-specific band is depicted. Lanes 1-5 are visual representations of the RpoS levels in $E$. coli $A M 111 \mathrm{~F}^{\prime}$ harbouring the following plasmids. Lanes: 1, pESE102 $\left(h f q_{E C}\right) ; 2$, pESE75 $\left(h f q_{E c(75)}\right) ; 3$, pESP82 $\left(h f q_{P_{a}}\right) ; 4$, pESPGm $\left(h f q_{P_{a}}: a a c C 1\right)$; 5 , pUC18 (control). Lane 6, RpoS ${ }^{-}$strain RH90. No RpoS signal was detected for this strain. (b) Graphical representation of the results presented in (a). Quantification of the Western blot signals was done with the ImageQuant software. Values were normalized to the RpoS signal obtained from AM111F'(pUC18), which was set at 1 . Results represent data from triplicate experiments; the error bars represent SD.

\section{Both $\mathrm{Hfq}_{P a}$ and $\mathrm{Hfq}_{E C(75)}$ stimulate the expression of rpos}

Previous studies by Muffler et al. (1996) and by Brown \& Elliott (1996) have demonstrated that Hfq is required for the efficient translation of $r p o S$ in E. coli and $S$. typhimurium, respectively. We therefore asked whether $\mathrm{Hfq}_{P a}$ and $\mathrm{Hfq}_{E c(75)}$ showed a similar positive effect on the translation of $r p o S$ to that shown by $\mathrm{Hfq}_{E c}$. The $h f q_{E c}, h f q_{P a}$ and $h f q_{E c(75)}$ genes, encoded by pESE102, pESP82 and pESE75, respectively, were induced in AM111F' and the differences in the RpoS levels were determined by quantitative Western blotting. The induction of $h f q_{E c}$ and $h f q_{E c(75)}$ (Fig. 2a, lanes 1, 2 and Fig. 2 b) resulted in a similar increase ( $\sim 12$-fold) in the RpoS concentration when compared to that present in the $\mathrm{Hfq}^{-}$strains $\mathrm{AM} 111 \mathrm{~F}^{\prime}$ (pESPGm) and $\mathrm{AM} 111 \mathrm{~F}^{\prime}$ (pUC18) (Fig. 2a, lanes 4 and 5 and Fig. 2b) and RH90 (Fig. $2 \mathrm{a}$, lane 6 and Fig. 2b). The expression of $h f q_{P a}$ (Fig. $2 \mathrm{a}$, lane 3 and Fig. 2b) resulted in an approximately sevenfold increase in the RpoS concentration when compared to the control strains. Whether this results from the apparently reduced levels of $\mathrm{Hfq}_{p a}$ present, when compared to those of $\mathrm{Hfq}_{E c}$ or $\mathrm{Hfq}_{E c(75)}$, remains to be determined.

\section{$\mathrm{Hfq}_{P a}$ and $\mathrm{Hfq}_{E c}$ show the same regulatory effects on RpoS-independent genes}

Several studies have suggested that Hfq acts as global regulator, which affects the expression of RpoS-dependent as well as RpoS-independent genes (Muffler et al., 1997; Tsui et al., 1997; Vytvytska et al., 2000). To test whether $\mathrm{Hfq}_{P a}$ and $\mathrm{Hfq}_{E c}$ show the same alteration 

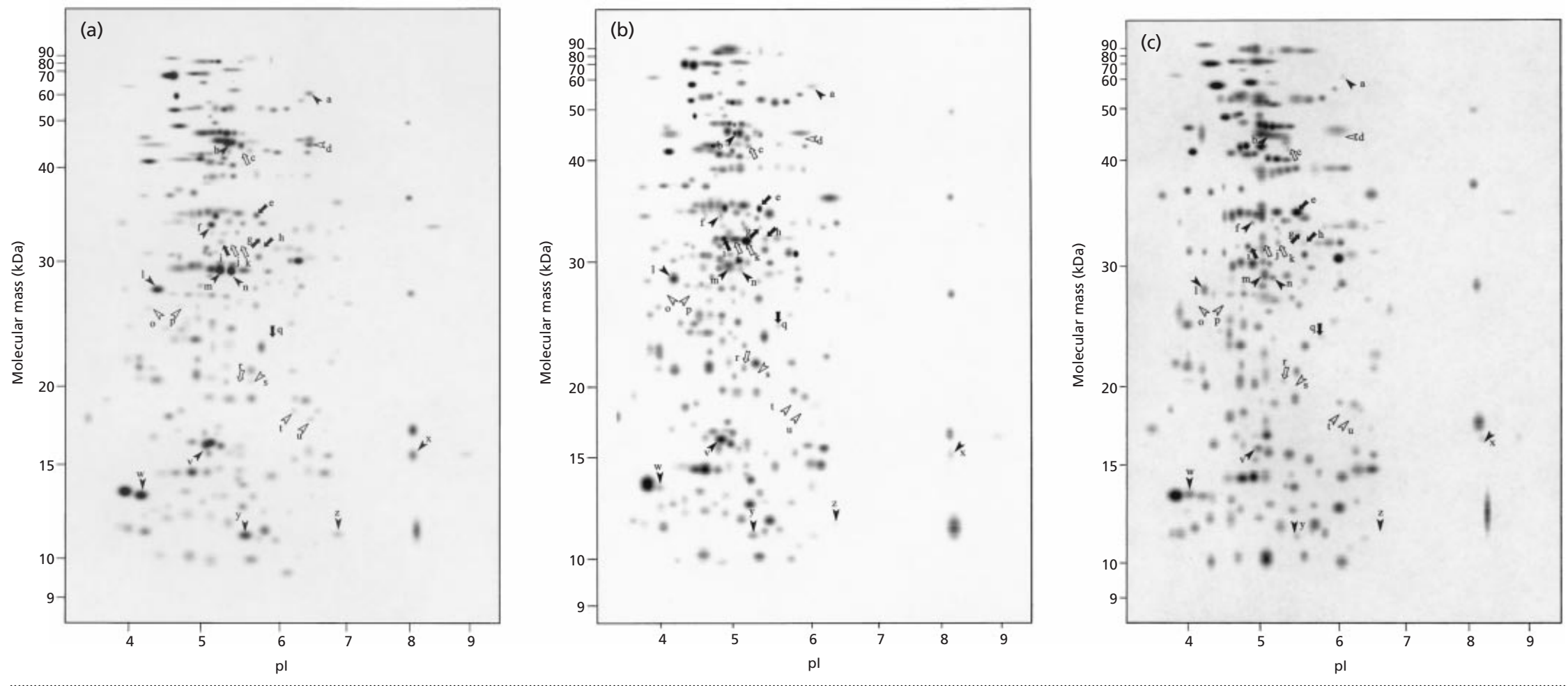

Fig. 3. Two-dimensional protein synthesis pattern of $E$. coli IM1101 bearing pUC18 (a), pESE102 (b) and pESP82 (c), respectively. Total cellular protein extracts were analysed. The $\mathrm{pH}$ gradient in the first dimension ranged from 3 to 10 (from left to right). Proteins whose synthesis was decreased in the presence of Hfa are depicted by solid arrowheads; those proteins whose synthesis was turned off in the presence of Hfq are indicated by open arrowheads. The proteins whose synthesis was enhanced in the presence of Hfq are indicated by solid arrows. Proteins which were absent in IM1101(pUC18) and present in the strains containing the plasmidencoded $\mathrm{Hfq}_{\mathrm{Pa}}$ or $\mathrm{Hfq}_{E C}$ are indicated by open arrows. 
Table 2. Regulatory effects by Hfq on the synthesis of RpoS-independent genes

\begin{tabular}{|c|c|c|c|}
\hline \multicolumn{2}{|c|}{ Putative protein } & pI Value & $\begin{array}{l}\text { Molecular mass } \\
\qquad(\mathrm{kDa})\end{array}$ \\
\hline \multicolumn{4}{|c|}{$\begin{array}{l}\text { Increased protein synthesis in the presence of } \mathrm{Hfq} \\
\text { (solid arrows in Fig. 3) }\end{array}$} \\
\hline (e) & Malate dehydrogenase & $5 \cdot 55$ & $35 \cdot 5$ \\
\hline (g) & $\begin{array}{l}\text { 2,3,4,5-Tetrahydropyridine-2-carboxylate } \\
\text { N-succinyltransferase }\end{array}$ & $5 \cdot 51$ & $31 \cdot 7$ \\
\hline & - & $5 \cdot 58$ & $32 \cdot 7$ \\
\hline & - & $5 \cdot 21$ & $32 \cdot 8$ \\
\hline (q) $\mathrm{A}$ & Adenylate kinase & $5 \cdot 60$ & $22 \cdot 5$ \\
\hline \multicolumn{4}{|c|}{$\begin{array}{l}\text { Induced protein synthesis in the presence of } \mathrm{Hfq} \\
\text { (open arrows in Fig. 3) }\end{array}$} \\
\hline & D-Aspartate aminotransferase & $5 \cdot 40$ & $42 \cdot 0$ \\
\hline & - & $5 \cdot 32$ & $32 \cdot 4$ \\
\hline & - & $5 \cdot 41$ & $32 \cdot 4$ \\
\hline & - & $5 \cdot 40$ & $20 \cdot 1$ \\
\hline \multicolumn{4}{|c|}{$\begin{array}{l}\text { Decreased protein synthesis in the presence of Hfq } \\
\text { (solid arrowheads in Fig. 3) }\end{array}$} \\
\hline & Periplasmic oligopeptide-binding protein & $5 \cdot 93$ & $56 \cdot 1$ \\
\hline & Elongation factor-Tu $(\mathrm{EF}-\mathrm{Tu})$ & $5 \cdot 32$ & $44 \cdot 6$ \\
\hline & Elongation factor-Ts (EF-Ts) & $5 \cdot 15$ & $33 \cdot 6$ \\
\hline (l) & Chemotaxis protein CHEZ & $4 \cdot 51$ & $28 \cdot 7$ \\
\hline & Tryptophan synthase $\alpha$-chain & $5 \cdot 30$ & $28 \cdot 7$ \\
\hline (n) & Outer-membrane protein A (OmpA) & $5 \cdot 34$ & $28 \cdot 6$ \\
\hline & $\begin{array}{l}\text { Deoxypyridine- } 5^{\prime} \text {-triphosphate } \\
\text { nucleotidohydrolase }\end{array}$ & $5 \cdot 03$ & $16 \cdot 1$ \\
\hline$(\mathrm{w})$ & - & $4 \cdot 24$ & $12 \cdot 2$ \\
\hline$(\mathrm{x})$ & - & $8 \cdot 27$ & $14 \cdot 5$ \\
\hline (y) & - & $5 \cdot 46$ & $10 \cdot 3$ \\
\hline (z) & - & $6 \cdot 71$ & $10 \cdot 4$ \\
\hline \multicolumn{4}{|c|}{$\begin{array}{l}\text { Protein synthesis is turned off in the presence of } \mathrm{Hfq} \\
\text { (open arrowheads in Fig. 3) }\end{array}$} \\
\hline (d) & - & $6 \cdot 15$ & $44 \cdot 3$ \\
\hline & - & $4 \cdot 38$ & $26 \cdot 5$ \\
\hline & - & $4 \cdot 82$ & $26 \cdot 9$ \\
\hline$(\mathrm{s})$ & - & $5 \cdot 50$ & $20 \cdot 2$ \\
\hline & - & $6 \cdot 00$ & $17 \cdot 4$ \\
\hline & - & $6 \cdot 28$ & $16 \cdot 8$ \\
\hline
\end{tabular}

in the expression of RpoS-independent genes, we compared the two-dimensional gel electrophoretic patterns of total-cellular-protein synthesis in IM1101(pESE102) and IM1101(pESP82) with that of the $\mathrm{RpoS}^{-} \mathrm{Hfq}^{-}$ control strain IM1101(pUC18). As mentioned above, although the protein levels of $\mathrm{Hfq}_{E c}$ and $\mathrm{Hfq}_{P a}$ seem to vary in strains IM1101(pESE102) and IM1101(pESP82) no gross difference was observed in their protein profile. (Fig. $3 \mathrm{~b}-\mathrm{c})$. This again showed that $\mathrm{Hfq}_{P a}$ can functionally replace $\mathrm{Hfq}_{E c}$ and that the C-terminal end of $\mathrm{Hfq}_{E c}$ is not necessary for its function. When compared to the $\mathrm{RpoS}^{-} \mathrm{Hfq}^{-}$control strain, the synthesis of at least five proteins was found to be enhanced in the presence of $\mathrm{Hfq}$ (indicated by solid arrows, Fig. 3a-c), whereas Hfq appears to be essential for the synthesis of four proteins (marked by open arrows, Fig. $3 a-c)$. In contrast, the synthesis of at least six proteins was found to be turned off in the presence of $\mathrm{Hfq}$ (indicated by open arrowheads, Fig. $3 \mathrm{a}-\mathrm{c}$ ) and the synthesis of 11 proteins was decreased in the presence of $\mathrm{Hfq}$ (indicated by solid arrowheads in Fig. $3 \mathrm{a}-\mathrm{c})$. In accordance with a recent study (Vytvytska et al., 2000), OmpA was found among these 11 proteins (Table 2 ; protein $\mathrm{n}$ ). Using the E. coli Swiss-2D PAGE, we have attempted to identify the proteins whose synthesis was affected by Hfq. Among the 26 proteins, 11 proteins were tentatively assigned (Table 2, a-z).

Suh et al. (1999) have reported that RpoS mediates the resistance of $P$. aeruginosa to heat shock, $\mathrm{H}_{2} \mathrm{O}_{2}$ and osmotic stress. Additionally, RpoS affects the accumulation of exotoxin $\mathrm{A}$, pyoverdin and alginate, which 
seem to be important for $P$. aeruginosa to survive adverse conditions during infection. Given that $\mathrm{Hfq}_{P a}$ affected the expression of E. coli rpoS (see Fig. 2) in a positive manner it remains to be seen whether it has the same role in $P$. aeruginosa. In addition, studies are currently under way to test whether $\mathrm{Hfq}_{P a}$ directly affects the expression of $P$. aeruginosa genes, as was indicated in this study for a number of E. coli genes.

\section{ACKNOWLEDGEMENTS}

We would like to thank Dr A. Hengge-Aronis (University of Berlin, Germany), Dr A. Ishihama (National Institute of Genetics, Shizuoka, Japan) and Dr F. Norel for their gifts of bacterial strains and materials. Preliminary sequence data were obtained from the Institute for Genomic Research (http://www.tigr.org). Sequencing of $P$. aeruginosa PAO1 was accomplished with support from the Cystic Fibrosis Foundation, the University of Washington Genome Center and the PathoGenesis Cooperation. This work was supported within the framework of the Special Research Program (017) on 'Modulators of RNA Fate and Function' by grant F1715 from the Austrian Science Fund (FWF) to U.B.

\section{REFERENCES}

Altschul, S. F., Gish, W., Miller, W., Myers, E. W. \& Lipman, D. J. (1990). Basic local alignment search tool. J Mol Biol 215, 403-410.

Azam, T. A., Hiraga, S. \& Ishihama, A. (2000). Two types of localization of the DNA-binding proteins within the Escherichia coli nucleoid. Genes Cells 5, 613-626.

Bodey, G. P., Bolivar, R., Fainstein, V. \& Jadeja, L. (1983). Infections caused by Pseudomonas aeruginosa. Rev Infect Dis $\mathbf{5}$, 279-313.

Brown, L. \& Elliott, T. (1996). Efficient translation of the RpoS sigma factor in Salmonella typhimurium requires host factor I, an RNA-binding protein encoded by the $h f q$ gene. J Bacteriol 178, 3763-3770.

Brown, L. \& Elliott, T. (1997). Mutations that increase expression of the $r p o S$ gene and decrease its dependence on $h f q$ function in Salmonella typhimurium. J Bacteriol 179, 656-662.

Brückner, R. (1992). A series of shuttle vectors for Bacillus subtilis and Escherichia coli. Gene 122, 187-192.

Carmichael, G. G., Weber, K., Niveleau, A. \& Wahba, A. J. (1975). The host factor required for RNA phage $\mathrm{Q} \beta$ RNA replication in vitro. J Biol Chem 250, 3607-3612.

Chuang, D. Y., Kyeremeh, A. G., Gunji, Y., Takahara, Y., Ehara, Y. \& Kikumoto, T. (1999). Identification and cloning of an Erwinia carotovora subsp. carotovora bacteriocin regulator gene by insertional mutagenesis. J Bacteriol 181, 1953-1957.

Cunning, C., Brown, L. \& Elliott, T. (1998). Promotor substitution and deletion analysis of upstream region required for rpoS translational regulation. J Bacteriol 180, 4564-4570.

Deckert, G., Warren, P. V., Gaasterland, T. \& 12 other authors (1998). The complete genome of the hyperthermophilic bacterium Aquifex aeolicus. Nature 392, 353-358.

de Fernandez, M. T. F., Eoyang, L. \& August, J. T. (1968). Factor fraction required for the synthesis of bacteriophage $\mathrm{Q} \beta$-RNA. Nature 219, 588-590.

de Fernandez, M. T. F., Hayward, W. S. \& August, J. T. (1972). Bacterial proteins required for replication of $\mathrm{Q} \beta$ ribonucleic acid. J Biol Chem 247, 824-831.
Durand, J. M., Bjork, G. R., Kuwae, A., Yoshikawa, M. \& Sasakawa, C. (1997). The modified nucleoside 2-methylthio-N6isopentenyladenosine in tRNA of Shigella flexneri is required for expression of virulence genes. J Bacteriol 179, 5777-5782.

Fleischmann, R. D., Adams, M. D., White, O. \& 37 other authors (1995). Whole-genome random sequencing and assembly of Haemophilus influenzae Rd. Science 269, 496-512.

Holloway, B. W. (1955). Genetic recombination in Pseudomonas aeruginosa. J Gen Microbiol 13, 572-581.

Kajitani, M. \& Ishihama, A. (1991). Identification and sequence determination of the host factor gene for bacteriophage $\mathrm{Q} \beta$. Nucleic Acids Res 19, 1063-1066.

Kajitani, M., Kato, A., Wada, A., Inokuchi, Y. \& Ishihama, A. (1994). Regulation of the Escherichia coli hfq gene encoding the host factor for phage Q $\beta$. J Bacteriol 176, 531-534.

Kaminski, P. A., Desnoues, N. \& Elmerich, C. (1994). The expression of nifA in Azorbizobium caulinodans requires a gene product homologous to Escherichia coli HF-I, an RNA-binding protein involved in the replication of phage $\mathrm{Q} \beta$ RNA. Proc Natl Acad Sci US A 91, 4663-4667.

Laemmli, U. K. (1970). Cleavage of structural protein during the assembly of the head of bacteriophage T4. Nature 227, 680-685.

Lange, R. \& Hengge-Aronis, R. (1991). Identification of a central regulator of stationary-phase gene expression in Escherichia coli. Mol Microbiol 5, 49-59.

Lanzer, M. \& Bujard, H. (1988). Promoters largely determine the efficiency of repressor action. Proc Natl Acad Sci USA 85, 8973-8977.

Majdalani, N., Cunning, C., Sledjeski, D. D., Elliott, T. \& Gottesman, S. (1998). DsrA RNA regulates translation of RpoS message by an anti-antisense mechanism, independent of its action as an antisilencer of transcription. Proc Natl Acad Sci U S A 95, 12462-12467.

Miller, J. H. (1972). Experiments in Molecular Genetics. Cold Spring Harbor, NY: Cold Spring Harbor Laboratory.

Muffler, A., Fischer, D. \& Hengge-Aronis, R. (1996). The RNAbinding protein HF-I, known as a host factor for phage $\mathrm{Q} \beta$ RNA replication, is essential for $r p o S$ translation in Escherichia coli. Genes Dev 10, 1143-1151.

Muffler, A., Traulsen, D. D., Fischer, D., Lange, R. \& HenggeAronis, R. (1997). The RNA-binding protein HF-I plays a global regulatory role which is largely, but not exclusively, due to its role in expression of the $\sigma^{\mathrm{s}}$ subunit of RNA polymerase in Escherichia coli. J Bacteriol 179, 297-300.

Nakao, H., Watanabe, H., Nakayama, S. \& Takeda, T. (1995). yst gene expression in Yersinia enterocolitica is positively regulated by a chromosomal region that is highly homologous to Escherichia coli host factor 1 gene ( $h f q)$. Mol Microbiol 18, 859-865.

Ried, G., Koebnik, R., Hindennach, I., Mutschler, B. \& Henning, U. (1994). Membrane topology and assembly of the outer membrane protein OmpA of Escherichia coli K12. Mol Gen Genet 243, 127-135.

Robertson, G. T. \& Roop, R. M. (1999). The Brucella abortus host factor I (HF-I) protein contributes to stress resistance during stationary phase and is a major determinant of virulence in mice. Mol Microbiol 34, 690-700.

Rose, R. E. (1988). The nucleotide sequence of pACYC184. Nucleic Acid Res 16, 355.

Schuppli, D., Miranda, G., Tsui, H. T., Winkler, M. E., Sogo, J. M. \& Weber, H. (1997). Altered 3'-terminal RNA structure in phage $\mathrm{Q} \beta$ adapted to host factor-less Escherichia coli. Proc Natl Acad Sci U S A 94, 10239-10242. 
Sledjeski, D. D., Gupta, A. \& Gottesman, S. (1996). The small RNA, DsrA, is essential for the low temperature expression of RpoS during exponential growth in Escherichia coli. EMBO J 15, 3993-4000.

Sledjeski, D. D., Whitman, C. \& Zhang, A. (2001). Hfq is necessary for regulation by the untranslated RNA DsrA. J Bacteriol 183, 1997-2005.

Stover, C. K., Pham, X. Q., Erwin, A. L. \& 28 other authors (2000). Complete genome sequence of Pseudomonas aeruginosa PAO1, an opportunistic pathogen. Nature 406, 959-964.

Suh, S., Silo-Suh, L., Woods, D. E., Hassett, D. J., West, S. E. H. \& Ohman, D. E. (1999). Effect of rpoS mutation on the stress response and expression of virulence factors in Pseudomonas aeruginosa. J Bacteriol 181, 3890-3897.

Thompson, J. D., Higgins, D. G. \& Gibson, T. J. (1994). CLUSTAL W : improving the sensitivity of progressive multiple sequence alignment through sequence weighting, position-specific gap penalties and weight matrix choice. Nucleic Acids Res 22, 4673-4680.

Tsui, H. T., Leung, H. E. \& Winkler, M. E. (1994). Characterization of broadly pleiotropic phenotypes caused by an $h f q$ insertion mutation in Escherichia coli K-12. Mol Microbiol 13, 35-49.

Tsui, H. T., Feng, G. \& Winkler, M. E. (1997). Negative regulation of $m u t S$ and $m u t H$ repair gene expression by the Hfq and RpoS global regulators of Escherichia coli K-12. J Bacteriol 179, 7476-7487.

Vytvytska, O., Jakobsen, J. S., Balcunaite, G., Andersen, J. S., Baccarini, M. \& von Gabain, A. (1998). Host factor I, Hfq, binds to
Escherichia coli ompA mRNA in a growth rate-dependent fashion and regulates its stability. Proc Natl Acad Sci US A 95, 1411814123.

Vytvytska, O., Moll, I., Kaberdin, V. R., von Gabain, A. \& Bläsi, U. (2000). Hfq (HF1) stimulates ompA mRNA decay by interfering with ribosome binding. Genes Dev 14, 1109-1118.

Wassarman, K. M., Repoila, F., Rosenow, C., Storz, G. \& Gottesman, S. (2001). Identification of novel small RNAs using comparative genomics and microarrays. Genes Dev 15, 16371651.

West, S. E. H., Schweizer, H. P., Dall, C., Sample, A. K. \& RunyenJanecky, L. J. (1994). Construction of improved EscherichiaPseudomonas shuttle vectors derived from pUC18/19 and sequence of the region required for their replication in Pseudomonas aeruginosa. Gene 128, 81-86.

Yanisch-Perron, C., Vieira, J. \& Messing, J. (1985). Improved M13 cloning vectors and host strains: nucleotide sequence of M13mp18 and pUC19 vectors. Gene 33, 103-119.

Zhang, A., Altuvia, S., Tiwari, A., Argaman, L., Hengge-Aronis, R. \& Storz, G. (1998). The OxyS regulatory RNA represses $r p o S$ translation and binds the $\mathrm{Hfq}$ (HF-I) protein. EMBO $J$ 17, 6061-6068.

Received 6 August 2001; revised 16 October 2001; accepted 9 November 2001. 